\author{
Abstracta Iranica \\ Abstracta Iranica Revue bibliographique pour le domaine irano-aryen \\ Volume 37-38-39 | 2018 \\ Comptes rendus des publications de 2014-2016
}

\title{
Henning Börm. «A Threat or a Blessing? The Sasanians and the Roman Empire »
}

\section{Rika Gyselen}

\section{(2) OpenEdition}

1 Journals

\section{Édition électronique}

URL : http://journals.openedition.org/abstractairanica/42646

DOI : 10.4000/abstractairanica.42646

ISBN : 1961-960X

ISSN : 1961-960X

Éditeur :

CNRS (UMR 7528 Mondes iraniens et indiens), Éditions de l'IFRI

Référence électronique

Rika Gyselen, «Henning Börm. "A Threat or a Blessing? The Sasanians and the Roman Empire » », Abstracta Iranica [En ligne], Volume 37-38-39 | 2018, document 18, mis en ligne le 10 mars 2018, consulté le 29 septembre 2020. URL : http://journals.openedition.org/abstractairanica/42646 ; DOI : https://doi.org/10.4000/abstractairanica.42646

Ce document a été généré automatiquement le 29 septembre 2020

Tous droits réservés 


\title{
Henning Börm. «A Threat or a Blessing? The Sasanians and the Roman Empire »
}

\author{
Rika Gyselen
}

\section{RÉFÉRENCE}

Henning Börm. « A Threat or a Blessing? The Sasanians and the Roman Empire », in C. Binder, H. Börm, A. Luther (ed.), Diwan. Untersuchungen zu Geschichte und Kultur des Nahen Ostens und des östlichen Mittelmeerraumes im Altertum. Festschrift für Josef Wiesehöfer zum 65. Geburtstag, Duisburg, Wellem Verlag, 2016, p. 615-646.

Dans «Une menace ou une bénédiction?» sont passées en revue les guerres que Romains et Sassanides se sont livré périodiquement et les raisons qui varient selon l'époque. Une seule période - le Ve siècle - est symptomatique d'une attitude nonguerrière de la part des deux puissances qui cherchent plutôt à maintenir la paix. L'auteur met ce retournement d'attitude du côté sassanide sur le compte d'un changement dans l'idéologie royale qui intègre la tradition de la dynastie légendaire des Kayanides et qui, à leur instar, porte son intérêt vers l'est. Du côté romain, l'empereur n'ayant plus besoin de s'investir personnellement dans les batailles militaires, choisit d'installer sa cour dans la capitale orientale et se préoccupe de maintenir la paix dans les territoires orientaux. Il trouve dans le roi sassanide un partenaire puissant, capable de contrôler le Caucase pour empêcher l'infiltration de guerriers nomades et ayant suffisamment d'autorité pour dissuader ses alliés de s'attaquer aux biens romains en Orient. 


\section{AUTEURS}

\section{RIKA GYSELEN}

CNRS, Mondes iranien et indien 